The effects of lecturer commitment on student perceptions of teaching quality and student satisfaction in Chinese higher education

Xiao, J

http://hdl.handle.net/10026.1/3938

10.1080/1360080x.2014.992092

Journal of Higher Education Policy and Management Informa UK Limited

All content in PEARL is protected by copyright law. Author manuscripts are made available in accordance with publisher policies. Please cite only the published version using the details provided on the item record or document. In the absence of an open licence (e.g. Creative Commons), permissions for further reuse of content should be sought from the publisher or author. 
Xiao, J. and Wilkins, S. (2015). The effects of lecturer commitment on student perceptions of teaching quality and student satisfaction in Chinese higher education. Journal of Higher Education Policy and Management, 37(1), 98-110.

\title{
The effects of lecturer commitment on student perceptions of teaching quality and student satisfaction in Chinese higher education
}

\author{
Jian Xiao ${ }^{a}$ and Stephen Wilkins ${ }^{b^{*}}$ \\ ${ }^{a}$ Hengyang Normal University, China \\ ${ }^{b}$ Plymouth University, UK
}

\begin{abstract}
Student satisfaction has become an important concept in higher education because students are paying higher tuition fees and increasingly seeing themselves as customers and because satisfaction is commonly used as an indicator of quality by quality assurance agencies and the compilers of rankings and league tables. In business organisations, it has been established that employee commitment has a significant impact on employee performance and customer satisfaction. The purpose of this research is to examine the effects of lecturer commitment on student perceptions of teaching quality and student satisfaction. The sample comprised 24 lecturers and 456 students at one Chinese university. Data were obtained through self-administered paper-based questionnaires. A model linking lecturer commitment with students' perceived teaching quality and student satisfaction was created and the hypotheses were tested using structural equation modelling. It was found that lecturer commitment to students' academic achievement and lecturer commitment to the social integration of students are both positively related to student satisfaction. However, lecturer commitment to the social integration of students did not appear to influence students' perceptions of teaching quality. The implications for higher education institutions are discussed.
\end{abstract}

Keywords: lecturer commitment; teaching quality; student relationships; student satisfaction; structural equation modelling

\section{Introduction}

In the mid 1990s, a government initiative known as 'Project 911' advocated the establishment of 100 new universities (Lang \& Zha, 2004). In addition, legislation passed in 2002 allowing private universities in China to earn an 'appropriate profit' encouraged the establishment of new private universities (Altbach, 2004). The expansion of higher education capacity in China saw the number of undergraduate students in China increase from 3.41 million in 1998 to 13.33 million in 2004 (Wan, 2006). The private institutions that have entered the sector now compete vigorously with the public universities for students. As a result of China's one child policy, the number of high school graduates is currently decreasing each year. Nevertheless, the number of students enrolled in higher education in 2009 was 21.45 million (Ministry of Education of the People's Republic of China, 2010a) and in the same year the gross enrolment rate in higher education for 18-22 year olds was 24.2 per cent, compared to 3.5 per cent in 1991 (Ministry of Education of the People's Republic of China, 2010b). Higher education institutions are now considering much more carefully how they can achieve a competitive advantage to attract more students and this has led many institutions to take an increased interest in student satisfaction.

Dill and Soo (2005) suggest that students are the key stakeholders in higher education and their opinion is important in improving the quality of higher education and the 
Xiao, J. and Wilkins, S. (2015). The effects of lecturer commitment on student perceptions of teaching quality and student satisfaction in Chinese higher education. Journal of Higher Education Policy and Management, 37(1), 98-110.

reputation and images of universities. Tuition fees were introduced in Chinese higher education in 1998 (Marcucci \& Johnstone, 2007). Since then, students choose a university and pay their tuition fees and this transaction is essentially the same model as any other product or service. Therefore, it is not unreasonable to regard students as customers as well as partners (Yorke, 1999). In fact, when students pay tuition fees, they typically consider themselves as customers and the way they are treated by universities - for example, encouraged to express their dissatisfaction if they have any concerns - promotes the dominant marketplace customer model (Svensson \& Wood, 2007). However, the concept of student satisfaction is still widely debated among higher education practitioners and researchers because students must be partners in the learning process (Tam, 2001).

Student satisfaction has become an important concept in higher education because it is a measure often used in rankings and league tables, and the higher ranked institutions benefit by attracting the top professors and students, higher levels of external funding, and from being able to charge the highest tuition fees (Wilkins \& Huisman, 2012). Institutions can also benefit from student satisfaction in several other ways; for example, satisfied students are less likely to drop out (Tinto, 1993), more likely to achieve higher grades (Bean \& Bradley, 1986), and more likely to engage in positive word of mouth (Alves \& Raposo, 2009).

Since the mid-1990s, practitioners and researchers have increasingly considered the links between the quality and commitment of faculty, teaching quality and student satisfaction (Tsui \& Cheng, 1999). Employee commitment has been found to have a positive relationship with employee performance (Chen, Tsui, \& Farh, 2002) and customer satisfaction (Liao \& Chuang, 2004). We argue that these relationships are particularly valid on university campuses, where lecturers play a key role in the learning process. Thus, the purpose of this research is to examine the effects of lecturer commitment on student perceptions of teaching quality and student satisfaction.

\section{Student satisfaction}

Students in universities are increasingly regarded as customers because in most countries they must now pay tuition fees to undertake higher education. Given the competitive environment in which most institutions find themselves, university managers have begun to place greater emphasis on satisfying the needs and expectations of students (Cheng \& Tam, 1997). In business, customer satisfaction is the main measure of an individual's feeling of contentment after making a purchase of a good or service (Fornell, 1992). Elliot and Healy (2001) suggest that student satisfaction refers to a student's evaluation of their experiences with education services provided by institutions in the short-term. Student satisfaction results when actual or perceived experiences meet or exceed the individual's expectations.

Numerous studies have been undertaken to measure student satisfaction in universities (Butt \& Rehman, 2010). Student satisfaction is multi-dimensional and depends on the clarity of goals which a student desires to achieve at their university and in their education (Hartman \& Schmidt, 1995) and it derives from continually repeated experiences in campus life (Elliott \& Shin, 2010). Student satisfaction is influenced by various factors. Grossman (1999) found that trust is a significant factor that influences student satisfaction. Students might be more likely to trust those lecturers they perceive as committed to students' wellbeing and academic achievement. Trust can be built in higher education through meeting or exceeding students' expectations, which might involve treating students in a polite and consistent manner, giving help and assessment feedback in a caring way, and dealing with problems and complaints quickly and effectively. 
Xiao, J. and Wilkins, S. (2015). The effects of lecturer commitment on student perceptions of teaching quality and student satisfaction in Chinese higher education. Journal of Higher Education Policy and Management, 37(1), 98-110.

Although student satisfaction might be influenced by the experiences a student has with university staff, systems, procedures and support mechanisms, several researchers have concluded that classroom experiences and the perceived quality of education received are the key determinants of student satisfaction (e.g. Athiyaman, 1997; Elliott \& Healy, 2001). Hill, Lomas, and MacGregor (2003) found that student satisfaction was influenced by the quality of lecturers and classroom delivery; the quality of feedback given to students in lessons and on assignments; and the interpersonal relationships between students and lecturers. Empirical research has indicated the importance of students' perceptions of their learning in determining student satisfaction and teacher evaluations. For example, Patrick (2011) found that once the perceived amount of learning was accounted for, students' academic achievement did not have a significant effect on teacher ratings.

Given that the study conducted by Hill, Lomas, and MacGregor (2003) was based on students in the United Kingdom (UK), and, given the very different cultures and education systems in the UK and China, it cannot be assumed that Chinese students are influenced by the same things as UK students. However, given that the key outcome of education is the acquisition of knowledge and skills, perceived teaching quality and course experiences are likely to be important factors that determine student satisfaction in any country or culture. This research focuses on student satisfaction with lecturers and teaching, rather than overall satisfaction with a programme or institution.

\section{Teaching quality}

In all service organisations, service quality is important. Service quality may be considered to exist when a customer's perception of a service and how it was performed exceeds his or her expectations; it represents an individual's attitude gained from long-term evaluation (Parasuraman, Zeithaml, \& Berry, 1988). Delivering service quality helps an organisation to retain customers (Zeithaml, Berry, \& Parasuraman, 1993) and achieve repeat purchases (Schneider \& Bowen, 1995). Research on quality in higher education has indicated that teaching quality is hard to define since quality may mean different things to different people (Harvey \& Green, 1993). However, Sahney, Banwet, and Karunes (2004) explain education quality as the constructive alignment of education output to planned goals, specifications and requirements. The majority of service quality research in higher education has concentrated on the attitudes of students, and in many countries independent quality assurance bodies assess student experiences and perceptions (Christou, 2002). The theoretical framework proposed by Owlia and Aspinwall's (1996) to assess education quality focuses on teaching, competence, attitude, content and academic resources.

The new generation of students, who increasingly regard themselves as customers, have become more aware of how they are taught and how they learn, and they have become more selective and interactive in their education choices and how they participate in the education process (Petruzzellis, D'Uggento, \& Romanazzi, 2006). Previous research has found that students perceive lecturers as effective when they are helpful, caring, understanding, enthusiastic and entertaining (Davison \& Price, 2009; Delucchi, 2000). Teaching quality has received increased interest from all stakeholders, including parents, governments and the media. In the increasingly competitive higher education arena, universities and colleges have used teaching quality, educational outcomes and student satisfaction as indicators to achieve differentiation from competitors. 
Xiao, J. and Wilkins, S. (2015). The effects of lecturer commitment on student perceptions of teaching quality and student satisfaction in Chinese higher education. Journal of Higher Education Policy and Management, 37(1), 98-110.

\section{Lecturer commitment}

Mowday, Porter, and Steers (1982) identify the features of organisational commitment as the strong desire to remain a member of the organisation, the willingness to exert high levels of effort on behalf of the organisation, and an acceptance of the values and goals of the organisation. Therefore, employee commitment represents a workers' psychological attachment to their workplace (Meyer \& Allen, 1997). Mowday, Steers, and Porter (1979) argue that employee commitment exists when the goals of the organisation and the individual are the same. Employee commitment influences many behavioural outcomes, such as job satisfaction, job performance, absenteeism and turnover; it can be regarded as a motivating force, an attitude, or a set of behavioural intentions (Bateman \& Strasser, 1984).

Meyer and Allen (1997) propose a three-component model which consists of three distinctive forms: affective, continuance and normative commitment. Affective commitment is the emotional attachment to the organisation; continuance commitment refers to an employee's perception that leaving the organisation would have a high opportunity cost; and normative commitment refers to the sense of obligation to the organisation and a desire to remain in the organisation. Although Meyer and Allen (1997) and Meyer, Stanley, Herscovitch, and Topolnytsky (2002) suggest that affective and normative commitment particularly influence how an employee carries out their work and performs their responsibilities, we argue that in an educational context the commitment of lecturers might be suitably assessed through measurement of their normative commitment to achieving students' academic attainment and to maintaining positive student-student and teacherstudent relationships.

Research has found that an individual's personal characteristics do not usually play an essential role in determining employee commitment (Morris, Lydka, \& O'Creevy, 1993). However, job characteristics, such as professional skills needed, employee involvement and stress experienced, have been found to influence employee motivation, performance and satisfaction (Hackman \& Oldham, 1980). High job involvement, as experienced by lecturers in higher education, typically builds employee commitment (Parker \& Jary, 1995). Employees are also influenced by levels of organisation support, style of leadership, human resource management practices, perceived external prestige (Chen, Tsui, \& Farh, 2002).

In an educational context, professional commitment and organisational commitment are two forms of lecturer commitment, usually recognised as commitment to professional teaching and commitment to the institution. Mowday, Steers, and Porter (1979) argue that teacher commitment can be measured according to the extent to which individuals recognise organisational goals and values, work to achieve the goals of the organisation, regard themselves as part of the organisation and desire to remain a member of the organisation. However, it is lecturer commitment in the forms of commitment to students, commitment to the profession and commitment to the organisation that determine teaching and learning outcomes.

Many studies have examined lecturer and teacher commitment towards students, and the focus has tended to be on the employee's commitment to organisational goals and specifically the achievement of high academic attainment, which promotes the institution's reputation and attracts more high quality students and faculty (Hopkins \& Stern, 1996). Lecturer commitment has been found to be related to lecturer job satisfaction (DarlingHammond, 1990).

Previous research demonstrates that lecturer commitment is a critical predictor of lecturers' work performance, absenteeism and turnover (Cheng, 1990), and Park, Henkin, 
Xiao, J. and Wilkins, S. (2015). The effects of lecturer commitment on student perceptions of teaching quality and student satisfaction in Chinese higher education. Journal of Higher Education Policy and Management, 37(1), 98-110.

and Egley (2005) found that teacher commitment is the most effective method to improve organisational success. Although previous research has examined the link between teacher commitment and student achievement (e.g. Park, Henkin, \& Egley, 2005), there has been little research on the link between teacher commitment and student satisfaction. However, Patrick (2011) found a link between lecturer conscientiousness and students' evaluations of teaching, and Ahmad, Ather, and Hussain (2014) argue that affective commitment can act as a mediator in the relationship between conscientiousness and job performance.

\section{Conceptual framework}

Empirical research has concluded that student satisfaction, student loyalty, and positive word of mouth for a university are influenced by teaching quality, academic achievement and social integration activities (Brookes \& Becket, 2007; Douglas, McClelland, \& Davies, 2008; Petruzzellis, D'Uggento, \& Romanazzi, 2006). We hypothesise that teaching quality and student satisfaction are both dependent upon lecturer commitment. Previous research has suggested a link between lecturer commitment and student learning (Coladarci, 1992; Ware \& Kitsantas, 2007). Clayson and Sheffet (2006) found that perceptions of teachers' personalities were associated with student teaching evaluations. Patrick (2011) notes that committed lecturers are enthusiastic about their jobs, and lecturer enthusiasm has been found to be associated with student ratings. The committed lecturer typically puts more effort into lesson planning and resourcing, as well as classroom delivery, so students are likely to perceive that committed lecturers are delivering higher quality teaching.

Nir (2002) suggests that lecturer commitment comprises both a commitment to students' academic achievement and a commitment to achieving good social relations in the classroom, which involves integrating students in the class and achieving a purposeful learning atmosphere that satisfies the individual student's needs. In the current higher education environment, many lecturers are required to design programme delivery in ways that ensure international and host country students work and learn together effectively (Rienties, Héliot, \& Jindal-Snape, 2013). Our conceptual model recognises lecturer commitment to academic achievement and social integration, hence:

Hypothesis 1: Lecturer commitment to academic achievement is positively related to students' perceived teaching quality

Hypothesis 2: Lecturer commitment to social integration is positively related to students' perceived teaching quality

Teaching is at the core of the service provided by higher education institutions, which explains why it dominates stakeholders' perceptions of overall quality (Bigne, Moliner, \& Sanchez, 2003; Schneider \& Bowen, 1995). Students' evaluations of teaching effectiveness and quality can be used to understand student satisfaction (Marsh \& Roche, 1997). Lecturers must understand what students need and want in order to deliver the learning experience that will enable the students to achieve their goals and objectives through the effective acquisition of knowledge and skills (Chung \& McLarney, 2000). Committed lecturers will be concerned with both academic achievement and social integration. For example, good social relationships are required for effective group work, which can lead to both superior academic achievement and student satisfaction. Sojkin, Bartkowiak, and Skuza (2012) found that social conditions, and therefore implicitly social relationships, were a key 
Xiao, J. and Wilkins, S. (2015). The effects of lecturer commitment on student perceptions of teaching quality and student satisfaction in Chinese higher education. Journal of Higher Education Policy and Management, 37(1), 98-110.

determinant of student satisfaction. Students who achieve their goals and objectives, and who perceive they received quality teaching, are likely to be more satisfied with their lecturer and overall educational experience. Thus:

Hypothesis 3: Lecturer commitment to academic achievement is positively related to student satisfaction.

Hypothesis 4: Lecturer commitment to social integration is positively related to student satisfaction.

Hypothesis 5: Students' perceived teaching quality is positively related to student satisfaction.

The conceptual model presented in Figure 1 summarises the relationships investigated in this study.

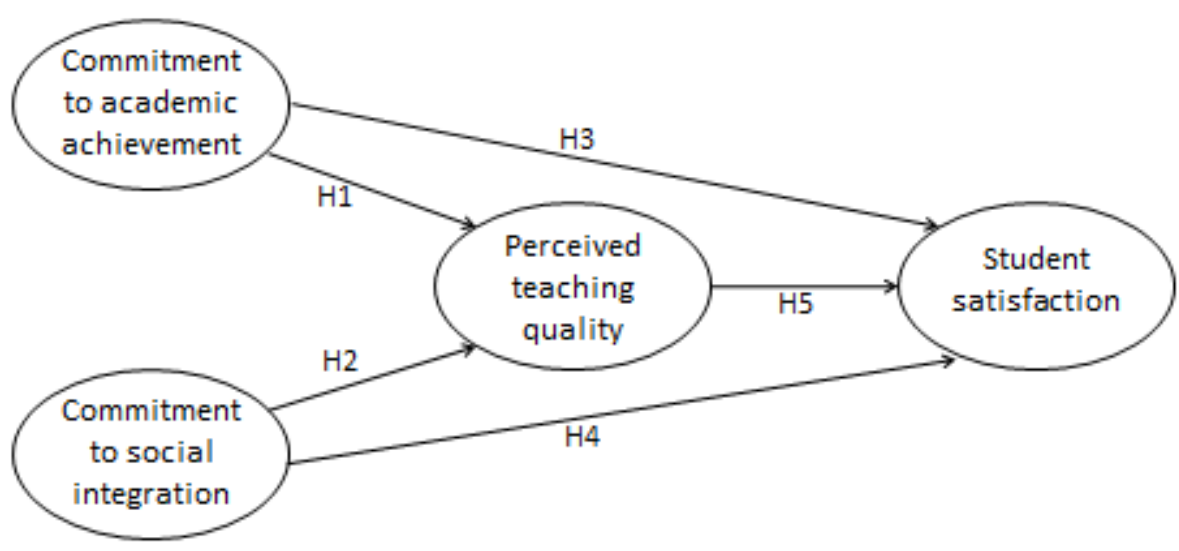

Figure 1. Proposed conceptual model.

\section{Method}

The study involved two questionnaires, one completed by lecturers and the other by students, at a university in China. The sample comprised 24 lecturers and 456 students. The self-administered paper-based questionnaires were distributed via a manager of the university and a senior official of the students' union. All respondents were invited volunteers but the usable response rate for the student questionnaire was over 95 per cent given that the questionnaire was handed out and collected during normal lessons and students felt obliged to complete it. Given that the questionnaire completed by the lecturers involved them declaring their perceptions of their own commitment, the manager selected a range of lecturers that she believed had a range of commitment levels and who she believed would complete the questionnaire honestly given the assurance of anonymity. Of the students, 63.6 per cent were female and 36.4 per cent were male. Approximately one quarter came from each of the four years of the degree programme. The students were taking a range of subjects that included English and American literature, Computer Science, History, Mathematics and Psychology. Each subject provided between 14.3 per cent and 
Xiao, J. and Wilkins, S. (2015). The effects of lecturer commitment on student perceptions of teaching quality and student satisfaction in Chinese higher education. Journal of Higher Education Policy and Management, 37(1), 98-110.

19.0 per cent of the total sample. The 24 lecturers taught the modules delivered to the student respondents.

Both questionnaires consisted largely of questions answered with 7-point Likert scales, where $1=$ strongly disagree and $7=$ strongly agree. The questions were presented in the Chinese language. The measures for lecturer commitment were based on the scale developed by Nir (2002). Exploratory factor analysis, using principal components with varimax rotation, was conducted to examine the factor structure. Two factors emerged, one corresponding to commitment to academic achievement and the other to commitment to social integration. Two items were removed from Nir's eight item scale as they both achieved factor loadings lower than 0.45 .

Thus, Nir's scale was divided so that three items were used to measure commitment to academic achievement and three items were used to measure commitment to social integration. Examples of items for commitment to academic achievement include 'All students can succeed and it is my mission to ensure their success' and 'I can't face my students if I don't put all my efforts into increasing their knowledge and skills', while examples of items for commitment to social integration are 'It is my responsibility to ensure good social relations among my students' and 'I believe that being an educator makes me responsible for my students' integration in the classroom'. These two scales had Cronbach's alpha values of 89 and .87, indicating good internal consistency.

The measures for teaching quality were taken from Lizzio, Wilson, and Simons (2002). The five item scale produced a Cronbach's alpha value of .84. Examples of items include 'My lecturer provided clear and useful explanations of ideas' and 'My lecturer showed an interest in students' opinions and attempted to understand the difficulties students were having'. The five item scale for student satisfaction was based on Paechter, Maier, and Macher (2010). The Cronbach's alpha value of .79 indicated satisfactory internal consistency. Examples of items include 'My lecturer supported and counselled me with regard to my learning progress' and 'My lecturer has a good rapport with students and helped students to develop self-confidence'.

To ensure validity and reliability, the draft questionnaires were subjected to a pretest that involved 5 lecturers and 10 students. Other than some minor rephrasing of questions on both questionnaires, to make items clearer and more understandable, the pretest did not reveal any other issues that needed addressing and all items seemed to work well. To establish convergent and discriminant validity of the scales, we ran confirmatory factor analysis. All item loadings were on their respective scale and statistically significant. All variables yielded acceptable values for average variance extracted $(>.50)$ and construct reliability (> .70). The results of the measurement model indicates that the data fit the model reasonably well $\left(\chi_{(94)}^{2}=206.682, p<.001 ; \chi^{2} / d f=2.229 ; \mathrm{NFI}=.910 ; \mathrm{CFI}=.948\right.$; RMSEA $=.055)$.

\section{Results}

To test the hypotheses, a structural model was created and tested using AMOS (Version 20.0). Commitment to academic achievement and commitment to social integration were the two exogenous variables, while perceived teaching quality and student satisfaction were the two endogenous variables. The model estimates indicate that the data fits the model reasonably well $\left(\chi_{(92)}^{2}=198.820, p<.001 ; \chi^{2} / d f=2.161 ; \mathrm{NFI}=.913 ; \mathrm{CFI}=.951 ; \mathrm{RMSEA}=\right.$ .054). All the individual paths were significant at the .001 level, except the path linking lecturer commitment to social integration with students' perceived teaching quality. It 
Xiao, J. and Wilkins, S. (2015). The effects of lecturer commitment on student perceptions of teaching quality and student satisfaction in Chinese higher education. Journal of Higher Education Policy and Management, 37(1), 98-110.

should be remembered that that the results for which the hypotheses were supported indicate association between variables and not necessarily causal relationships (Tyler, Hilton III, Plummer, \& Barret, 2014). Table 1 presents the test results, showing the unstandardized coefficients, standard errors and critical ratios for the estimated paths.

Table 1. Summary of results for hypothesis testing.

\begin{tabular}{clcccc}
\hline Path & $B$ & $S E$ & C.R. & $\begin{array}{c}\text { Hypothesis } \\
\text { supported? }\end{array}$ \\
\hline H1 $\quad \begin{array}{l}\text { Academic achievement } \\
\rightarrow \text { Teaching quality }\end{array}$ & 1.088 & .075 & $14.588^{* * *}$ & Yes \\
H2 $\quad \begin{array}{l}\text { Social integration } \\
\rightarrow \text { Teaching quality }\end{array}$ & -.136 & .057 & -2.388 & No \\
H3 $\quad \begin{array}{l}\text { Academic achievement } \\
\rightarrow \text { Student satisfaction }\end{array}$ & .672 & .147 & $4.585^{* * *}$ & Yes \\
H4 $\begin{array}{l}\text { Social integration } \\
\rightarrow \text { Student satisfaction }\end{array}$ & .936 & .102 & $9.161^{* * *}$ & Yes \\
H5 $\quad \begin{array}{l}\text { Teaching quality } \\
\rightarrow \text { Student satisfaction }\end{array}$ & .501 & .109 & $4.612^{* * *}$ & Yes \\
\hline$* * * p<.001$ & & & &
\end{tabular}

\section{Discussion}

The purpose of this study was to test whether lecturer commitment is positively related to students' perceptions of teaching quality and student satisfaction. It was found that both lecturer commitment to students' academic achievement and lecturer commitment to the social integration of students are positively related to student satisfaction. Given that previous research has found teaching quality to be a key determinant of student satisfaction (e.g. Athiyaman, 1997; Elliott \& Healy, 2001; Hill, Lomas, \& MacGregor, 2003), it was not surprising that teaching quality was positively related to both lecturer commitment to academic achievement and student satisfaction. However, the path between lecturer commitment to the social integration and students' perceptions of teaching quality was not significant. This implies that students might have been satisfied with the lecturer's style of delivery, for example, involving students in their learning through group work and team 'games', even though such classroom methods were not perceived as representing high quality teaching.

Successful learning typically requires effective performance from both students and lecturers. Lecturers who are committed to the academic achievement of their students will spend more time and exert more effort into planning lessons, developing and acquiring learning resources, and thinking about how to convey information and monitor student progress. The committed lecturer is more likely, therefore, to demonstrate superior work performance and achieve higher student attainment. The lecturer who is committed to social integration is interested in satisfying individual learning needs and to identifying and dismantling the barriers to an individual's learning. Students will sense if a lecturer is interested in their academic performance and welfare, and if a lecturer does not seem motivated, it is far more likely that students will also not be motivated or committed to their studies. 
Xiao, J. and Wilkins, S. (2015). The effects of lecturer commitment on student perceptions of teaching quality and student satisfaction in Chinese higher education. Journal of Higher Education Policy and Management, 37(1), 98-110.

Lecturer commitment is important because it reflects an individual's interpretation of their job role as absorbing and meaningful. Lecturer commitment does not only have an impact on individual students; it is vital in achieving wider organisational quality, which can influence ratings and rankings compiled by quality assurance agencies and the media, as well as the perceptions of other external stakeholders, such as employers, parents and funding bodies (Kushman, 1992). Commitment to student learning includes lecturers' dedication to helping students learn regardless of their academic difficulties or social background. In the current environment in which students increasingly see themselves as customers, it is vital that they perceive they are receiving value for money and that they are guided and supported to achieve their academic potential.

The findings of this research suggest that high quality teaching is needed to achieve both high levels of student attainment and student satisfaction. Institutions must provide a work environment that encourages and supports high quality teaching. Given that lecturer salaries in China are not high compared to other professional work groups, managers must consider what motivates lecturers and how lecturers can be better incentivised and rewarded. Lecturers will show higher levels of commitment if they are given the right working conditions and if they are offered suitable rewards for superior performance.

\section{Conclusion}

Studying employee commitment is never easy; many individuals will not want to admit that they are not committed to their job and its task requirements. Although the lecturers in this study gave virtually no ' 1 's in their questionnaire responses and only a few '2's (corresponding with 'strongly disagree' and 'mostly disagree'), there were enough ' 2 's and ' 3 's in the sample to differentiate the commitment of lecturers. The lecturer responses suggest that the respondents answered the questions with a high degree of honesty. As well as highlighting the link between lecturer commitment and student satisfaction, this study reveals that there is a proportion of lecturers who may not be sufficiently committed to their job. As higher education is a people-based industry that relies on an individual employee's motivation and performance to achieve positive student and organisational outcomes, managers need to be aware of and monitor the commitment of individuals to maximise overall organisational performance.

This research is not without limitations. It relied on a relatively small sample in a single Chinese university. The results are not therefore generalisable across higher education institutions globally, let alone across China. Furthermore, the data is based on the selfreported perceptions of lecturers and students, which might not be accurate or reflect reality. The research identified and modelled two components of lecturer commitment, but there might be additional components that could be investigated and modelled, for example commitment to a subject discipline or to student employability and progression. Also, student satisfaction was modelled in this research as being determined by factors under the direct control or influence of lecturers, but in reality there are many things outside the lecturer's control - such as class size and the availability of learning resources - which might impact upon both lecturers' commitment and students' perceptions of teaching quality.

Despite the limitations, this research provides findings which support the proposition that student satisfaction with lecturers and teaching is influenced by lecturer commitment. Another interesting finding is that while lecturer commitment to social integration appears to not impact upon student's perceptions of teaching quality, it does significantly influence student satisfaction. One explanation for this finding is that many students do not like group 
work or team exercises as a learning method and hence these students may not associate these activities with high quality teaching even though they do help achieve social integration. However, many students do prefer student-centred activities such as group work over traditional lectures and this might explain the satisfaction among students resulting from teaching methods intended by lecturers to achieve social integration.

Previous research has found that teacher commitment can be influenced by the teacher's personal characteristics, such as gender and highest qualification held (Park, 2005), as well as student characteristics such as students' academic levels (Dannetta, 2002) and socioeconomic status (Rosenholtz \& Simpson, 1990). It should be noted that most of the existing research on teacher commitment has been undertaken in schools rather universities and it cannot be assumed that findings will be the same in higher education as secondary education. Future research could explore whether lecturer commitment varies according to things such as seniority, length of service and subject discipline.

A study by Felton, Mitchell, and Stinson (2004) found that students' ratings of lecturer quality were strongly correlated with ratings given for course easiness and lecturer's attractiveness. However, Tyler, Hilton III, Plummer, and Barret (2014) argue that while general correlation might exist between students' academic attainment and student evaluations of teaching, such correlation does not necessarily hold true for individual lecturers and courses. Other studies have found that student perceptions can easily be biased, for example against less experienced lecturers (Fries \& McNinch, 2003), older lecturers (Arbuckle \& Williams, 2003), and homosexual lecturers (Ewing, Stukas, \& Sheehan, 2003).

Future research could compare the role of lecturer commitment in relation to all the other potential influences on students' perceptions of teaching quality and student satisfaction, for example, by including lecturer commitment as one variable among others in regression analysis. Researchers could investigate whether student satisfaction with lecturers and teaching quality is influenced by the student's gender, the lecturer's gender, the lecturer's age and seniority, the lecturer's personality, subject discipline, level of study (i.e. undergraduate or graduate), and the student's academic attainment. It would be interesting and useful for institutions to also explore the wider benefits of lecturer commitment to the organisation and the strategies that might be used by educational managers to increase and maintain lecturer commitment.

\section{References}

Ahmad, J., Ather, M.R., \& Hussain, M. (2014). Impact of Big Five personality traits on job performance (Organizational commitment as a mediator). Management, Knowledge and Learning International Conference 2014, June 25-27, Portorož, Slovenia.

Altbach, P.G. (2004). The past and future of Asian universities: Twenty-first century challenges. In P.G. Altbach \& T. Umakoshi (Eds.), Asian Universities: Historical perspectives and contemporay challenges (pp. 13-32). Baltimore: Johns Hopkins University Press.

Alves, H., \& Raposo, M. (2009). The measurement of the construct satisfaction in higher education. Services Industries Journal, 29(2), 203-218.

Arbuckle, J., \& Williams, B.D. (2003). Students' perceptions of expressiveness: Age, and gender effects on teacher evaluations. Sex Roles, 49(9/10), 507-516. 
Xiao, J. and Wilkins, S. (2015). The effects of lecturer commitment on student perceptions of teaching quality and student satisfaction in Chinese higher education. Journal of Higher Education Policy and Management, 37(1), 98-110.

Athiyaman, A. (1997) Linking student satisfaction and service quality perceptions: The case of university education. European Journal of Marketing, 31(7), 528-540.

Bateman, T.S., \& Strasser, S. (1984). A longitudinal analysis of the antecedents of organizational commitment. Journal of Academy of Management, 27(1), 95-112.

Bean, J.P., \& Bradley, R.K. (1986). Untangling the student-performance relationship for college students. Journal for Higher Education, 57(4), 393-412.

Bigne, E., Moliner, M.A., \& Sanchez, J. (2003). Perceived quality and satisfaction in multiservice organisations: The case of Spanish public services. Journal of Services Marketing, 17(4), 420-442.

Brookes, M., \& Becket, N. (2007), Quality management in higher education: A review of international issues and practice. International Journal of Quality Standards, 1(1), 85-121.

Butt, B.Z., \& Rehman, K. (2010). A study examining the students satisfaction in higher education. Procedia - Social and Behavioral Sciences, 2(2), 5446-5450.

Chen, Z.X., Tsui, A.S., \& Farh, J.L. (2002). Loyalty to supervisor vs. organizational commitment: Relationships to employee performance in China. Journal of Occupational and Organizational Psychology, 75(3), 339-356.

Cheng, K.M. (1990). The culture of schooling in East Asia. In T. Takala (Ed.), Handbook of educational ideas and practices (pp. 163-173). London: Routledge.

Cheng, Y.C., \& Tam, W.M. (1997). Multi-models of quality in education. Quality Assurance in Education, 5(1), 22-31.

Christou, E. (2002). Revisiting competencies for hospitality management: Contemporary views of the stakeholders. Journal of Hospitality and Tourism Education, 14(1), 25-32.

Chung, E., \& McLarney, C. (2000). The classroom as a service encounter: Suggestions for value creation. Journal of Marketing Education, 24(4), 484-500.

Clayson, D.E., \& Sheffet, M.J. (2006). Personality and the student evaluation of teaching. Journal of Marketing Education, 28(2), 149-160.

Coladarci T. (1992). Teachers' sense of efficacy and commitment to teaching. Journal of Experimental Education, 60(4), 323-337.

Dannetta, V. (2002). What factors influence a teacher's commitment to student learning? Leadership and Policy in School, 1(2), 144-171.

Darling-Hammond, L. (1990). Teaching and knowledge: Policy issues posed by alternate certification for teachers. Peabody Journal of Education, 67(3), 123-154.

Davison, E., \& Price, J. (2009). How do we rate? An evaluation of online student evaluations. Assessment and Evaluation in Higher Education, 34(1), 51-65.

Delucchi, M. (2000). Don't worry, be happy: Instructor likeability, student perceptions of learning, and teacher ratings in upper-level sociology courses. Teaching Sociology, 28(3), 220-231.

Dill, D., \& Soo, M. (2005). Academic quality, league tables, and public policy: A cross-national analysis of university ranking systems. Journal of Higher Education, 49(4), 495-533.

Douglas J., McClelland, R., \& Davies, J. (2008). The development of a conceptual model of student satisfaction with their experience in higher education. Quality Assurance in Education, 16(1), 19-35.

Elliott K.M., \& Healy M.A. (2001). Key factors influencing student satisfaction related to recruitment and retention. Journal of Marketing for Higher Education, 10(4), 1-11.

Elliott, K.M., \& Shin, D. (2010). Student satisfaction: An alternative approach to assessing this important concept. Journal of Higher Education Policy and Management, 24(2), 197-209. 
Xiao, J. and Wilkins, S. (2015). The effects of lecturer commitment on student perceptions of teaching quality and student satisfaction in Chinese higher education. Journal of Higher Education Policy and Management, 37(1), 98-110.

Ewing, V.L., Stukas, A.A. Jr, \& Sheehan, E.P. (2003). Student prejudice against gay male and lesbian lecturers. Journal of Social Psychology, 143(5), 569-579.

Felton, J., Mitchell, J., \& Stinson, M. (2004). Web-based student evaluations of professors: The relations between perceived quality, easiness and sexiness. Assessment and Evaluation in Higher Education, 29(1), 91-108.

Fornell, C. (1992). A national customer satisfaction barometer: The Swedish experience. Journal of Marketing, 56(1), 6-21.

Fries, C.J., \& McNinch, R.J. (2003). Signed versus unsigned student evaluations of teaching: A comparison. Teaching Sociology, 31(3), 333-344.

Grossman, R.P. (1999). Relational versus discrete exchanges: The role of trust and commitment in determining customer satisfaction. Journal of Marketing Management, 9(2), 47-58.

Hackman, J.R., \& Oldham, G.R. (1980). Work redesign. Reading, MA: Addison-Wesley.

Hartman, D.E., \& Schmidt, S.L. (1995). Understanding student/alumni satisfaction from a consumer's perspective: The effects of institutional performance and program outcomes. Research in Higher Education, 36(2), 197-217.

Harvey, L., \& Green, D. (1993). Defining quality. Assessment and Evaluation in Higher Education, 18(1), 9-34.

Hill, Y., Lomas, L., \& MacGregor, J. (2003). Students' perceptions of quality in higher education. Quality Assurance in Education, 11(1), 15-20.

Hopkins, D., \& Stern, D. (1996). Quality teachers, quality schools: International perspectives and policy implications. Teaching and Teacher Education, 12(5), 501-517.

Kushman, J.W. (1992). The organizational dynamics of teacher workplace commitment: A study of urban elementary and middle schools. Educational Administration Quarterly, 28(1), 5-42.

Lang, D.W., \& Zha, Q. (2004). Comparing universities: A case study between Canada and China. Higher Education Policy, 17(4), 339-354.

Liao, H., \& Chuang, A. (2004). A multilevel investigation of factors influencing employee service performance and customer outcomes. Academy of Management Journal, 47(1), 41-58.

Lizzio, A., Wilson, K., \& Simons, R. (2002). University students perceptions' of the learning environment and academic outcomes: Implications for theory and practice. Studies in Higher Education, 27(1), 27-52.

Marcucci, P.N., \& Johnstone, D.B. (2007). Tuition fee policies in a comparative perspective: Theoretical and political rationales. Journal of Higher Education Policy and Management, 29(1), 25-40.

Marsh, H.W., \& Roche, L.A. (1997). Making students' evaluations of teaching effectiveness effective: The critical issues of validity, bias and utility. American Psychologist, 52(11), 1187-1197.

Meyer, J.P., \& Allen, N.J. (1997). Commitment in the workplace: Theory, research, and application. Thousand Oaks, CA: Sage.

Meyer, J.P., Stanley, D.J., Herscovitch, L., \& Topolnytsky, L. (2002). Affective, continuance, and normative commitment to the organization: A meta-analysis of antecedents, correlates, and consequences. Journal of Vocational Behavior, 61(1), 20-52.

Ministry of Education of the People's Republic of China (2010a). Number of students in regular HEls by field of study. 
Xiao, J. and Wilkins, S. (2015). The effects of lecturer commitment on student perceptions of teaching quality and student satisfaction in Chinese higher education. Journal of Higher Education Policy and Management, 37(1), 98-110.

www.moe.edu.cn/publicfiles/business/htmlfiles/moe/s4971/201012/113569.html. Accessed 5 July 2013.

Ministry of Education of the People's Republic of China (2010b). Gross enrolment rate of schools by level. www.moe.edu.cn/publicfiles/business/htmlfiles/moe/s4969/201012/113470.html. Accessed 5 July 2013.

Morris, T., Lydka, H., \& O'Creevy, M.F. (1993). Can commitment be managed? A longitudinal analysis of employee commitment and human resource policies. Human Resource Management Journal, 3(3), 21-42.

Mowday, R.T., Porter, L.W., \& Steers, R.M. (1982). Employee-organization linkages: The psychology of commitment, absenteeism, and turnover. New York: Academic Press.

Mowday, R.T., Steers, R.M., \& Porter, L.W. (1979). The measurement of organizational commitment. Journal of Vocational Behavior, 14(2), 224-247.

Nir, A.E. (2002). School-based management and its effect on teacher commitment. International Journal of Leadership in Education: Theory and Practice, 5(4), 323-341.

Owlia, M.S., \& Aspinwall, E.M. (1996). A framework for the dimensions of quality in higher education. Quality Assurance in Education, 4(2), 12-20.

Paechter, M., Maier, B., \& Macher, D. (2010). Students' expectations of, and experiences in e-learning: Their relation to learning achievements and course satisfaction. Computers and Education, 54(1), 222-229.

Parasuraman, A., Zeithaml, V.A., \& Berry, L.L. (1988). SERVQUAL: A multiple-item scale for measuring consumer perceptions of service quality. Journal of Retailing, 64(1), 12-37.

Park, I. (2005). Teacher commitment and its effects on student achievement in American high schools. Educational Research and Evaluation, 11(5), 461-485.

Park, S., Henkin, A.B., \& Egley, R. (2005). Teacher team commitment, teamwork and trust: Exploring associations. Journal of Educational Administration, 43(5), 462-79.

Parker, M., \& Jary, D. (1995). The McUniversity: Organization, management and academic subjectivity. Organization, 2(2), 319-338.

Patrick, C.L. (2011). Student evaluations of teaching: Effects of the Big Five personality traits, grades and the validity hypothesis. Assessment and Evaluation in Higher Education, $36(2), 239-249$.

Petruzzellis, L., D'Uggento, A.M., \& Romanazzi, A. (2006). Student satisfaction and quality of service in Italian universities. Managing Service Quality, 16(4), 349-364.

Rienties, B., Héliot, Y.F., \& Jindal-Snape, D. (2013). Understanding social learning relations of international students in a large classroom using social network analysis. Higher Education, 66(4), 489-504.

Rosenholtz, S.J., \& Simpson, C. (1990). Workplace conditions and the rise and fall of teachers' commitment. Sociology of Education, 63(4), 241-257.

Sahney, S., Banwet, D.K., \& Karunes, S. (2004). Conceptualizing total quality management in higher education. TQM Magazine, 16(2), 145-159.

Schneider, B. and Bowen, D.E. (1995). Winning the service game. Boston, MA: Harvard Business School Press.

Sojkin, B., Bartkowiak, P., \& Skuza, A. (2012). Determinants of higher education choices and student satisfaction: The case of Poland. Higher Education, 63(5), 565-581.

Svensson, G., \& Wood, G. (2007). Are university students really customers? When illusion may lead to delusion for all. International Journal of Educational Management, 21(1), 17-28. 
Tam, M. (2001). Measuring quality and performance in higher education. Quality in Higher Education, 7(1), 47-54

Tinto, V. (1993). Leaving college: Rethinking the causes and cures of student attrition. Chicago, IL: University of Chicago Press.

Tsui, K.T., \& Cheng, Y.C. (1999). School organizational health and teacher commitment: A contingency study with multi-level analysis. Educational Research and Evaluation, 5(3), 249-268.

Tyler, T.J., Hilton III, J., Plummer, K., \& Barret, D. (2014). Correlation between grade point averages and student evaluation of teaching scores: Taking a closer look. Assessment and Evaluation in Higher Education, 39(3), 339-348.

Wan, Y. (2006). Expansion of Chinese higher education since 1998: Its causes and outcomes. Asia Pacific Education Review, 7(1), 19-31.

Ware H., \& Kitsantas A. (2007). Teacher and collective efficacy beliefs as predictors of professional commitment. Journal of Educational Research, 100(5), 303-310.

Wilkins, S., \& Huisman, J. (2012). UK business school rankings over the last 30 years (19802010): trends and explanations. Higher Education, 63(3), 367-382.

Yorke, M. (1999). Leaving early: Undergraduate non-completion in higher education. London: Falmer Press.

Zeithaml, V.A., Berry, L.L., \& Parasuraman, A. (1993). The nature and determinants of customer expectations of service. Journal of the Academy of Marketing Science, 21(1), $1-12$. 